\title{
CD9, a Major Platelet Cell Surface Glycoprotein, Is a ROCA Antigen and Is Expressed in the Nervous System
}

\author{
Zaven Kaprielian, Kyung-Ok Cho, Michael Hadjiargyrou, and Paul H. Patterson \\ Biology Division, California Institute of Technology, Pasadena, California 91125
}

\begin{abstract}
We previously generated a monoclonal antibody (mAb), ROCA1, which binds preferentially to rostral versus caudal sympathetic ganglia and intercostal nerves. Two other mAbs, ROCA2 and B2C11, bind to the same structures but not in rostrocaudal gradients. All three mAbs recognize a $26 \mathrm{kDa}$ cell surface protein. Amino acid sequence data obtained from the affinity purified $26 \mathrm{kDa}$ protein showed some homology with human CD9, a tetraspan protein implicated in intercellular signaling in hematopoietic cells. Using the PCR, we obtained cDNA clones representing the entire rat CD9 coding sequence from sciatic nerve and sympathetic ganglia. ROCA1, ROCA2, and B2C11 each immunoprecipitate a $26 \mathrm{kDa}$ protein from $\mathrm{CHO}$ cells stably transfected with one of the clones, demonstrating that the ROCA cell surface antigen is indeed rat CD9. We find that CD9 mRNA is widely expressed, with particularly high levels present in a number of neural tissues. In situ hybridization demonstrates that peripheral neurons and Schwann cells, as well as adrenal chromaftin cells express CD9 mRNA. Consistent with immunoblot analyses showing that, unlike the ROCA1 epitope, the $26 \mathrm{kDa}$ protein is not expressed in a rostrocaudal gradient, we find similar levels of rat CD9 mRNA in rostral and caudal intercostal nerves. In developing postnatal rat sciatic nerve, CD9 mRNA levels are coordinately regulated with the expression of myelin genes. These results provide another example of a cell surface protein expressed by both hematopoietic and neural cells, and suggest a role for CD9 in intercellular signaling in the nervous system.
\end{abstract}

[Key words: CD9, tetraspan family, ROCA antigen, neurospecification, Schwann cell, platelets, adrenal chromaffin cells, myelin, cell surface]

Cell surface proteins play fundamental roles in cell-cell interactions in the nervous and hematopoietic systems. In the hematopoietic systcm, somc of these roles include platelet activation and aggregation, lymphocyte trafficking, and tumor cell motility. In the nervous system, cell surface proteins play key roles in neuron-neuron and neuron-glia interactions, and direct

\footnotetext{
Received Mar. 29, 1994; revised June 13, 1994; accepted July 12, 1994.

We thank Dr. Richard Akeson for mAb B2C1 1; Doreen McDowell for assistance in platelet and media preparation; Li Ching Lo for assistance in in situ hybridization; Lisa Banner, Ming Ji Fann, and Kai Zinn for help with primer selection and PCR analysis; and Joshua Sanes, Karen Allendorfer, and Shilpi Banerjee for critically reading the manuscript. This work was supported by an individual NRSA to Z.K., an American Heart Association Research Training fellowship to M.H., and a NINDS grant to P.H.P.

Correspondence should be addressed to Dr. Zaven Kaprielian, Division of Biology, 216-76, California Institute of Technology, Pasadena, CA 91125.

Copyright (C) 1995 Society for Neuroscience $0270-6474 / 95 / 150562-12 \$ 05.00 / 0$
}

the migration of neurons and glia, as well as axon outgrowth, guidance, and fasciculation. Many of these proteins belong to four major cell adhesion receptor families: cadherins, Ig superfamily, integrins, and selectins (Hynes and Lander, 1992). Mosi of these proteins possess single transmembrane domains or are linked to the membrane via a phosphoinositol anchor, and they contain one or more Ig domains, an EGF or fibronectin repeat, and a cysteine-rich repeat or a kinase domain. Hematopoietic and neural cells express members of each family, with the exception of the selectins, which have thus far been identified only in hematopoietic cells.

A new superfamily of cell surface proteins known as the tetraspan (Gil et al., 1992) or transmembrane 4 superfamily (TM4SF; Wright et al., 1993) has recently been identified. Members of this family include (1) the leucocyte proteins CD9 (Boucheix et al., 1991; Lanza et al., 1991; Martin-Alonso et al., 1992; Mitamura et al., 1992; Rubinstein et al., 1993a,b), MRP-1 (identical to human CD9; Miyake et al., 1991), CD37 (Classon et al., 1989), CD53 (Amiot, 1990; Angelisova et al., 1990), OX44 antigen (rat homolog of human CD53; Bellacosa et al., 1991), CD63/ME 491 (Hotta et al., 1988; Metzelaar et al., 1991), AD1 (rat homolog of human CD63/ME 491; Nishikata et al., 1992), R2/C33/IA4 (Gaugitsch et al., 1991; Imai et al., 1992; Gil et al., 1992, respectively), TAPA-1 (Oren et al., 1990; Andria et al., 1991), and A15 (Emi et al., 1993); (2) the tumor-associated antigens CO-029 (Szala et al., 1990) and L6 (Marken et al., 1992); (3) the lung epithelial protein TI-1 (Kallin et al., 1991); and (4) the schistosome surface proteins $\mathrm{Sm} 23$ (Wright et al., 1990) and Sj23 (Davern et al., 1991). The current model for the structure of superfamily members consists of four transmembrane domains divided by two extracellular loops, with cytoplasmic N- and C-termini (Horejsi and Vlcek, 1991; Levy et al., 1991; Reynolds et al., 1992; Tomlinson et al., 1993). While many of these proteins are known to be expressed in hematopoietic and a variety of other cells, littlc information is available on their distribution in the nervous system (Kemshead et al., 1982; Komada et al., 1983; Ross et al., 1986; Von dem Borne et al., 1989; Oren et al., 1990). Although the in vivo function of these proteins has yet to be elucidated, antibody perturbation experiments implicate certain tetraspan family members in neural cell adhesion, motility, and growth regulation (Anton et al., 1994; Hadjiargyrou and Patterson, 1994).

We previously demonstrated that the ROCAl mAb recognizes two distinct proteins $(60 \mathrm{kDa}$ and $26 \mathrm{kDa})$ in membrane/ cytoskeletal fractions of peripheral nerves and ganglia. The 60 $\mathrm{kDa}$ protein is expressed at higher levels in rostral than in caudal intercostal nerves, and has been identified as peripherin (Kaprielian and Patterson, 1993). In contrast, it is the ROCAl 
epitope on the $26 \mathrm{kDa}$ protein, and not the protein itself, that is preferentially visualized immunohistochemically in rostral nerves and ganglia (Suzue et al., 1990; Kaprielian and Patterson, 1993). We now have three mAbs against the $26 \mathrm{kDa}$ protein, ROCA1, ROCA2 (Kaprielian and Patterson, 1993; Tole and Patterson, 1993), and B2C11 (Akeson and Warren, 1984). Amino acid sequence data obtained from the affinity purified 26 $\mathrm{kDa}$ protein raised the possibility that it could be the rat homolog of human CD9 (Kaprielian and Patterson, 1993). Here we describe the isolation of cDNA clones encoding rat CD9, confirm that it is the ROCA surface antigen, and define the regions of CD9 that contain the epitope for each $\mathrm{mAb}$. In addition, we report the tissue, cell type, positional, and developmental expression of rat CD9 mRNA.

\section{Materials and Methods}

\section{Antibodies}

ROCA1 and ROCA2 are both IgG2b mouse mAbs that have been previously characterized (Suzue et al., 1990; Kaprielian and Patterson, 1993; Tole and Patterson, 1993). B2C11 is an IgG2a mouse mAb that has also been previously characterized (Akeson and Warren, 1984).

\section{Protein preparations and immunoblotting}

NP40 extracts of adult rat peripheral nerve membrane/cytoskeletal fractions were prepared as previously described (Kapriclian and Pattcrson, 1993). Platelet extracts were derived from membrane/cytoskeletal fractions of platelet rich plasma, prepared according to Boucheix et al., 1983. In brief, blood from freshly killed adult rats was first collected into $1 / 9$ volume of $0.13 \mathrm{M}$ sodium citrate, and then centrifuged at 1000 $\mathrm{rpm}(150 \times \mathrm{g})$ for $10 \mathrm{~min}$ in a Sorvall SS 34 rotor. The resulting pellet was discarded, while the supernatant, which contains the platelet-rich plasma (PRP), was then centrifuged at $100,000 \times g$ for $1 \mathrm{hr}$ in a Beckman $70 \mathrm{Ti}$ rotor. The pellets were resuspended in protease inhibitor-containing low-salt homogenization buffer (Kaprielian and Patterson, 1993). This material, which will be referred to as the platelet membrane/cytoskeletal fraction, was either used immediately or frozen at $-80^{\circ} \mathrm{C}$ until further use. Detergent extracts were obtained by solubilizing the membrane/cytoskeletal fraction with $1 \% \mathrm{NP} 40$ as previously described (Kaprielian and Patterson, 1993). Protein concentration was determined by the method of Lowry et al. (1951), and immunoblots were performed as previously described (Kaprielian and Patterson, 1993).

\section{Molecular cloning of rat $C D 9$}

Single strand cDNA was prepared from adult rat SCG and ScN RNA using Maloney murine leukemia virus reverse transcriptase (Promega) and oligo-dT primers. Two primers, NT17 and CT19, representing portions of the $\mathrm{N}$ - and $\mathrm{C}$-terminus of human/bovine $\mathrm{CD} 9$, respectively, were synthesized as follows: NT17, 5'-ATGCCGGTCAAAGGAGG3'; CT19, 5'-AAGCTTGACTCTAGACCAT-3'. Rat CD9 DNA was amplified by adding these two primers and Taq DNA polymerase (Promega) to SCG or ScN CDNA, and carrying out the following polymerase chain reaction (PCR): 40 cycles of $95^{\circ} \mathrm{C}$ for $1 \mathrm{~min}, 52^{\circ} \mathrm{C}$ for $1.5 \mathrm{~min}$, $72^{\circ} \mathrm{C}$ for $1.5 \mathrm{~min}$, and a final incubation at $72^{\circ} \mathrm{C}$ for $10 \mathrm{~min}$. The PCR products amplified from both the SCG and $\mathrm{ScN}$ templates each contained a major band of the expected size $(678 \mathrm{bp})$ on $2 \%$ agarose gels. These products were isolated and inserted into the Smal site of the pBluescript II SK+ (Stratagene) vector.

\section{DNA sequence analysis}

Two, independent subclones derived from each of the original PCR products named [Full ScN \#13 and Full ScN \#42 (from ScN cDNA), and Full SCG \#3 and Full SCG \#8 (from SCG cDNA)] were sequenced by the dideoxy chain termination method (Sanger et al., 1977) using double-stranded DNA as template and T7 DNA polymerase (Sequenase, U.S. Biochemicals). Both strands of each subclone were sequenced not only with the T3, SK, KS, and T7 primers (Stratagene), but also with the four internal primers: RCD9 189, 5'-GCTGGGGCCCTCATGATG-3'; RCD9 255, 5'-CTGGGATTGTTCTTCGGA-3'; RCD9 490, 5'-GAACAAGGATGAGCCCAG-3'; RCD9 550, 5'-GACATCTGCCCCAAAAAG- $3^{\prime}$. The sequences of these subclones proved to be identical except that at each of four positions one of the clones contained a nucleotide that was different from the one present in the other three. This analysis yielded a consensus nucleotide sequence for rat CD9 (see Fig. 2). Eight additional PCR-isolated cDNAs (four each from $\mathrm{ScN}$ and SCG RNA) were sequenced in one direction using the primers listed above. Six of these proved to be identical to the consensus rat CD9 sequence, while two contained single nucleotide differences. We allribute all of the single nucleotide changes to PCR errors. Searches for related sequences were performed using the BLAST program.

\section{Expression of rat $\mathrm{CD} 9$ in $\mathrm{CHO}$ cells}

Subcloning of $C D 9$ cDNA. The Full ScN \#13 cDNA was inserted into the pBluescript II SK + vector (described above). Digestion with BamHI and Xhol yielded a fragment containing all of the CD9 cDNA and approximately 50 bp of vector. This fragment was then subcloned into the BamHI/Xhol linearized eukaryotic expression vector, $\mathrm{pcDNAI} / \mathrm{neo}$ (Invitrogen). After transformation of bacteria, a plasmid with the intact 5'-3' CD9-cDNA insert was selected. Large amounts of this DNA were purified (Qiagen plasmid kit) and subsequently used for transfection.

Transfection. CHO cells were transfected by lipofectin (BRL) (Felgner et al., 1987). Briefly, cells were plated at $2.5 \times 10^{5 / 100 ~ m m ~ d i s h ~ a n d ~}$ grown overnight at $37^{\circ} \mathrm{C}$ in Dulbecco's modified Fagle's medium (DMEM) supplemented with 10\% fetal bovine serum (FBS, Hyclone) and penicillin-streptomycin $(50 \mathrm{U} / \mathrm{ml}$ and $50 \mu \mathrm{g} / \mathrm{ml}$, respectively). $\mathrm{Li}$ pofectin $(25 \mu \mathrm{g})$ was mixed with $5 \mu \mathrm{g}$ rat CD9 cDNA (construct) in 200 $\mu \mathrm{l}$ of serum-free DMEM and added to the cells in $5 \mathrm{ml}$ of serum-free medium. The cells were then incubated for $5 \mathrm{hr}$ after which the lipofectin-DNA medium was replaced by $10 \mathrm{ml}$ of serum-containing DMEM. Cells were finally incubated at $37^{\circ} \mathrm{C}$ for $48 \mathrm{hr}$ prior to the addition of $400 \mu \mathrm{g} / \mathrm{ml} \mathrm{G} 418$. Twelve days later colonies were isolated using cloning cylinders.

Fusion protein analysis. The MBP-CD9 fusion protein was generated by in-frame fusion to a maltose binding protein (New England Biolabs). Briefly, to obtain a cDNA encoding the large, putative extracellular domain of rat $\mathrm{CD} 9$, a PCR was carried out using a primer corresponding to amino acids 111 to 116 (ATGGATCCCACAAGGACGAGGTGATTAA), and another corresponding to amino acids $184-190$ (ATAAGCTTCACTTGCTGTGGAAGACCTC), along with Full ScN \#13 as a template. To facilitate the cloning, a BamHI site was incorporated into the $5^{\prime}$ end of the forward primer (underlined), and a HindIII site was incorporated into the $5^{\prime}$ end of the backward primer (underlined). The PCR product was extracted with phenol and chloroform, digested with BamHI and HindIII, and ligated with pMal-c2 vector that had been digested with BamHI and HindIII. The expression of this fusion protein was induced by $I P^{\prime} T G$ (isopropyl- $\beta$-D-thiogalactopyranoside), and sonicated $E$. coli extracts were subjected to SDS-PAGE (Smith and Johnson, 1988).

Immunoprecipitation. Stably transfected $\mathrm{CHO}$ cell lines were grown to confluency in $100 \mathrm{~mm}$ tissue culture dishes containing DME-10\% FBS. For metabolic labeling, the medium was replaced with $5 \mathrm{ml}$ of DME (without cysteine or methionine or serum) to which $500 \mu \mathrm{Ci}$ (final concentration $=100 \mu \mathrm{Ci} / \mathrm{ml})^{35} \mathrm{~S}$-methionine-translabel $(\mathrm{ICN})$ had been added, and the cells were then incubated for $3 \mathrm{hr}$ at $37^{\circ} \mathrm{C}$. Following the labeling period, cells were washed $3 \times$ with $5 \mathrm{ml}$ of phosphatebuffered saline (PBS; $0.9 \% \mathrm{NaCl}, 100 \mathrm{mM} \mathrm{NaPO}$ ) and lysed with $2 \mathrm{ml}$ of protease-inhibitor containing low salt homogenization buffer (set above) containing 1\% CHAPS (Boehringer Mannheim). After multiple rounds of trituration and vortexing, the cell extract was centrifuged at $100,000 \times g$ for $1 \mathrm{hr}$ in a Beckman Type 50 rotor. The resulting supernatant $(2 \mathrm{ml})$ was mixed with $150 \mu$ of Protein G-conjugated sepharose beads (Pharmacia) and rotated end-over-end for $3 \mathrm{hr}$ at room temperature. Then, $500 \mu \mathrm{l}$ of the preabsorbed extract was mixed with $500 \mu \mathrm{l}$ of ROCA1, ROCA2, or B2C11 hybridoma supernatant and rotated end-over-end for $12-16 \mathrm{hr}$ at $4^{\circ} \mathrm{C}$. After this incubation, $30 \mu \mathrm{l}$ of Protein G-conjugated sepharose beads were added to the mixture and the incubation was continued for another $3 \mathrm{hr}$ at room temperature. The beads were then centrifuged in a microfuge, the supernatant removed, and the beads washed three times with PBS containing $0.05 \%$ Tween- 20 by a series of resuspensions and centrifugations. After a final wash in PBS without detergent, the beads were placed in $1 \times$ nonreducing sample buffer for 5 min to elute bound antigens (Kaprielian and Patterson, 1993). Proteins were subjected to one-dimensional SDS-PAGE, and stained and destained as previously described (Kaprielian and Patterson, 1993). Immediately prior to drying, the gels were incubated in 


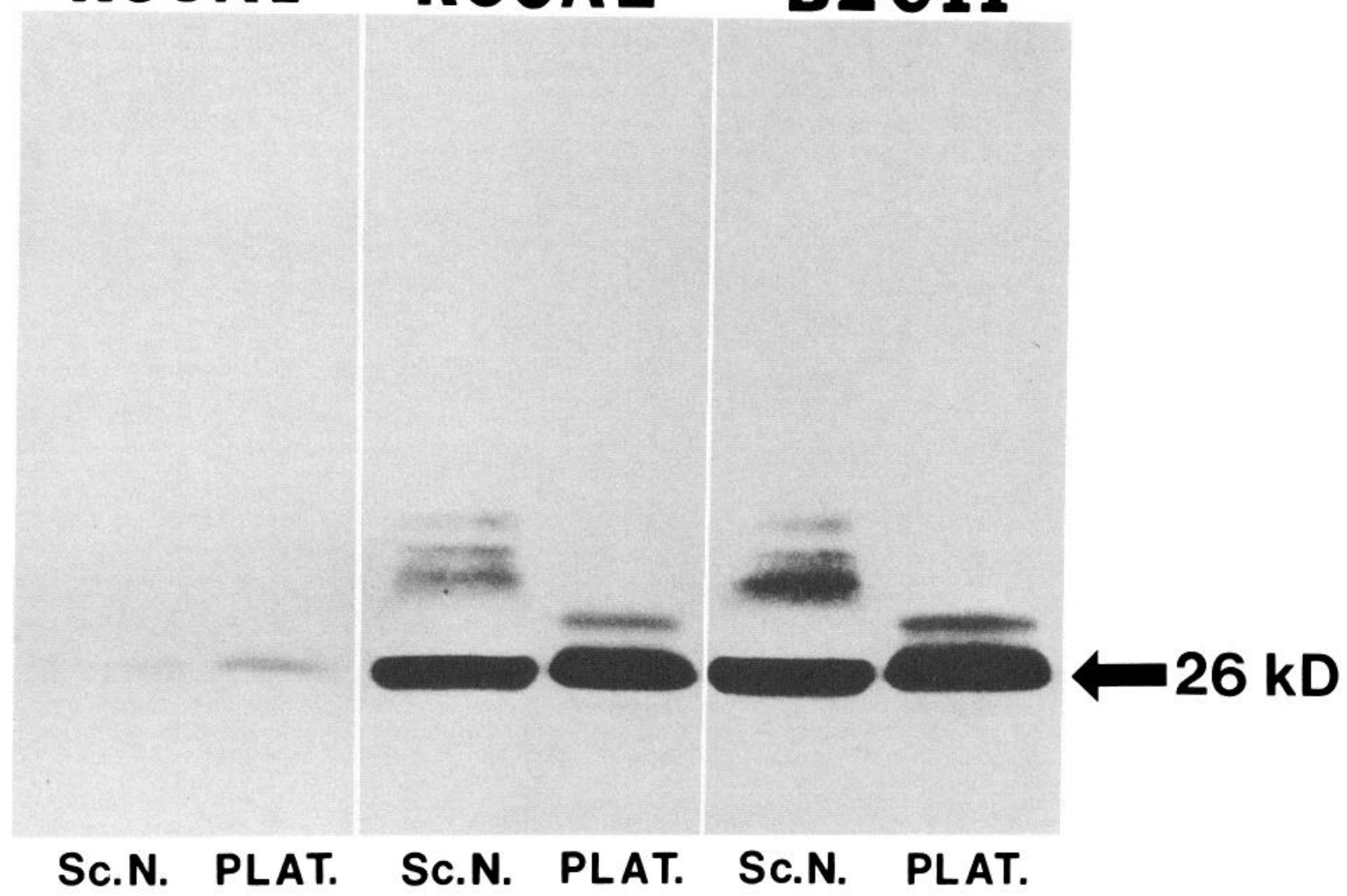

Figure 1. ROCA1, ROCA2, and B2C11 each bind a $26 \mathrm{kDa}$ protein in extracts of adult rat sciatic nerves and platelets. One percent NP-40 extracts of adult rat sciatic nerve and platelet membrane/cytoskeletal fractions were subjected to SDS-PAGE and immunoblot analysis as described in Materials and Methods. Each mAb binds a $26 \mathrm{kDa}$ protein in both sciatic nerve (SC.N.) and platelet (PLAT.) extracts. Primary antibody binding was visualized with a peroxidase-conjugated goat anti-mouse IgG secondary antibody. Approximately $40 \mu \mathrm{g}$ of protein was loaded in each lane.

Amplify (Amersham) for $30 \mathrm{~min}$ at room temperature. For autoradiography, dried gels were exposed to Kodak X-OMAT AR film for $12-24 \mathrm{hr}$ at $-80^{\circ} \mathrm{C}$

Immunocytochemistry. Transfected CHO cells were harvested, replated on sterile glass coverslips in serum-containing DMEM and grown for another $48 \mathrm{hr}$. Surface labeling of the cells with ROCA2 and B2C11 hybridoma supernatants was carried out as described in Hadjiargyrou and Patterson, 1994. Cells were photographed using a Nikon fluorescence microscope (Diaphot 300).

RNA Isolation and Northern analysis. Total RNA was prepared from various tissues as described by (Chomczynski and Sacchi 1987. RNA was separated on $1.5 \%$ agarose-formaldehyde gels, transferred to $\mathrm{Hy}$ bond nylon membrane (Amersham), and UV cross-linked (Stratagene). The PCR was used to generate CD9, MBP and $\mathrm{P}_{0}$ DNA by using the cloned cDNAs as templates, along with universal and reverse PCR primers. DNA for the $3^{\prime}$ end of $28 \mathrm{~S}$ rRNA was amplified using rat genomic DNA as the template and the following two PCR primers: forward, TGAAGCAGAATTCACCAAGC; backward, GTCGAGGGCTGACTTTCAAT (Choi, 1985). Each of the DNA probes were labeled with ${ }^{32} \mathrm{P}$ by the random priming method (Feinberg and Vogelstein, 1983). Blots were hybridized and washed according to Cho et al., 1991. The same blot was reused multiple times by placing the filter in boiling water for $1 \mathrm{~min}$ to strip previously bound radioactivity. Blots were exposed to either Kodak X-OMAT AR film or Molecular Dynamics Phosphor screens. Radioactivity was quantitated by scanning the Phos- phor screens with a Phosphorimager 400 S (Molecular Dynamics) and computations performed with IMAGEQUANT software.

In situ hybridization. The Full $\mathrm{ScN} \# 13 \mathrm{cDNA}$ was linearized with BamHI or EcoRI and transcribed with T7 or T3 RNA polymerase (MEGAscript Transcription Kit, Ambion) to generate antisense and sense rat CD9 RNA probes, respectively. Nonradioactive labeling was achieved by incorporating digoxygenin-11-UTP (Boehringer Mannheim) into the RNA probes during the transcription reaction. Tissue sections ( $15 \mu \mathrm{m}$ thick) on glass slides were hybridized in plastic slide mailers with digoxygenin-labeled probes by a modification (Birren et al., 1993) of the procedure of Harland (1991) with the following exceptions. All tissue sections were placed on untreated Super frost/Plus microscope slides (Fisher Scientific). Prehybridization and hybridization steps were carried out at $50^{\circ} \mathrm{C}$ (instead of $60^{\circ} \mathrm{C}$ ) for those sections containing sciatic or intercostal nerves. The alkaline phosphatase-conjugated anti-digoxygenin $\mathrm{Fab}$ fragments were preabsorbed with extracts of tissue parts dissected from developing or adult rats, depending on the age of the tissue to be examined.

\section{Results}

Expression of the ROCA surface antigen in platelets

To determine whether the ROCA mAbs recognize a $26 \mathrm{kDa}$ protein in hematopoietic cells we performed immunoblots on

Figure 2. Top, Amino acid sequence alignment of RAT, MOUSE, HUMAN, MONKEY, and BOVINE CD9. The putative transmembrane domains $(T M I-I V)$ are shaded. Identical residues between sequences are indicated by dashes. Bottom, Proposed topological model of CD9. Open circles represent residues that are identical across species. Solid circles identify interspecies amino acid differences. The two lightly shaded circles identify the positions of the two amino acids that are missing in rat CD9 (see top). The asterisk denotes the asparagine residue that is a possible site for $\mathrm{N}$-linked glycosylation. 
RAT

MOUSE

HUMAN

MONKEY

BOVINE

RAT

MOUSE

HUMAN

MONKEY

BOVINE

RAT

MOUSE

HUMAN

MONKEY

BOVINE

RAT MOUSE

HUMAN

MONKEY

BOVINE

RAT

MOUSE

HUMAN

MONKEY

BOVINE

51

TMII

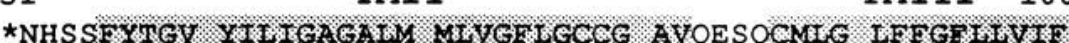

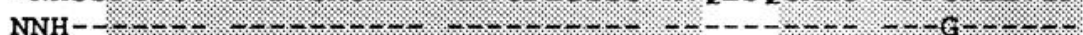

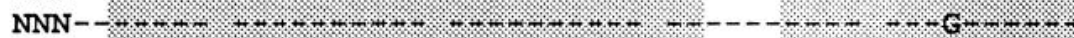

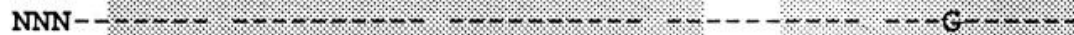

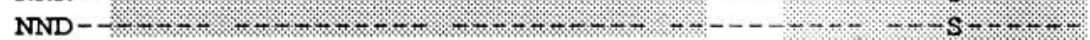

101 150

AIETAAAVKG YTHKDEVIKE LQEFYKDTYQ KLRNKDEPQR ETLKAIHMAL

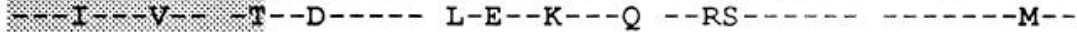

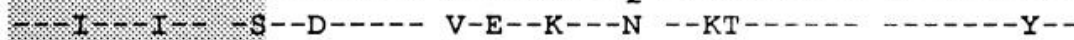

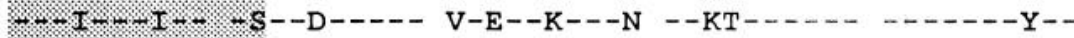

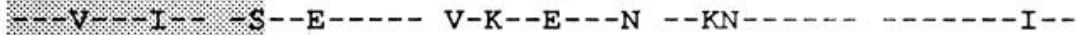

151

NCCGIAGGVE OFISDICPKK OVLESFOVKS CPDAIDEVFH SKFHITEAVE D---IA-PL- --IS-T--K- QLLESFQVKP --E--S-V-N N--- - * - : $\mathrm{N}---\mathrm{LA}-\mathrm{GV}-$--IS-I--K- DVLETFTVKS - -D--K-V-D N--- - D---LA-GV- --IS-I--K- DVLETFTIKS - -D--K-V-D N---- - - - * D---LT-VP- --LT-T--P- NLIDSLKTRP --E--D-I-R S----

SICIAVWIIFC MIISBMIIICEA IRRSREMV

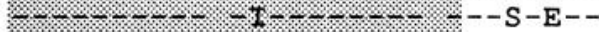

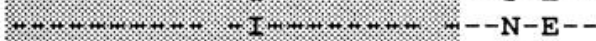

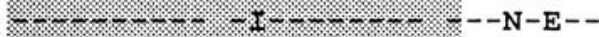

2.

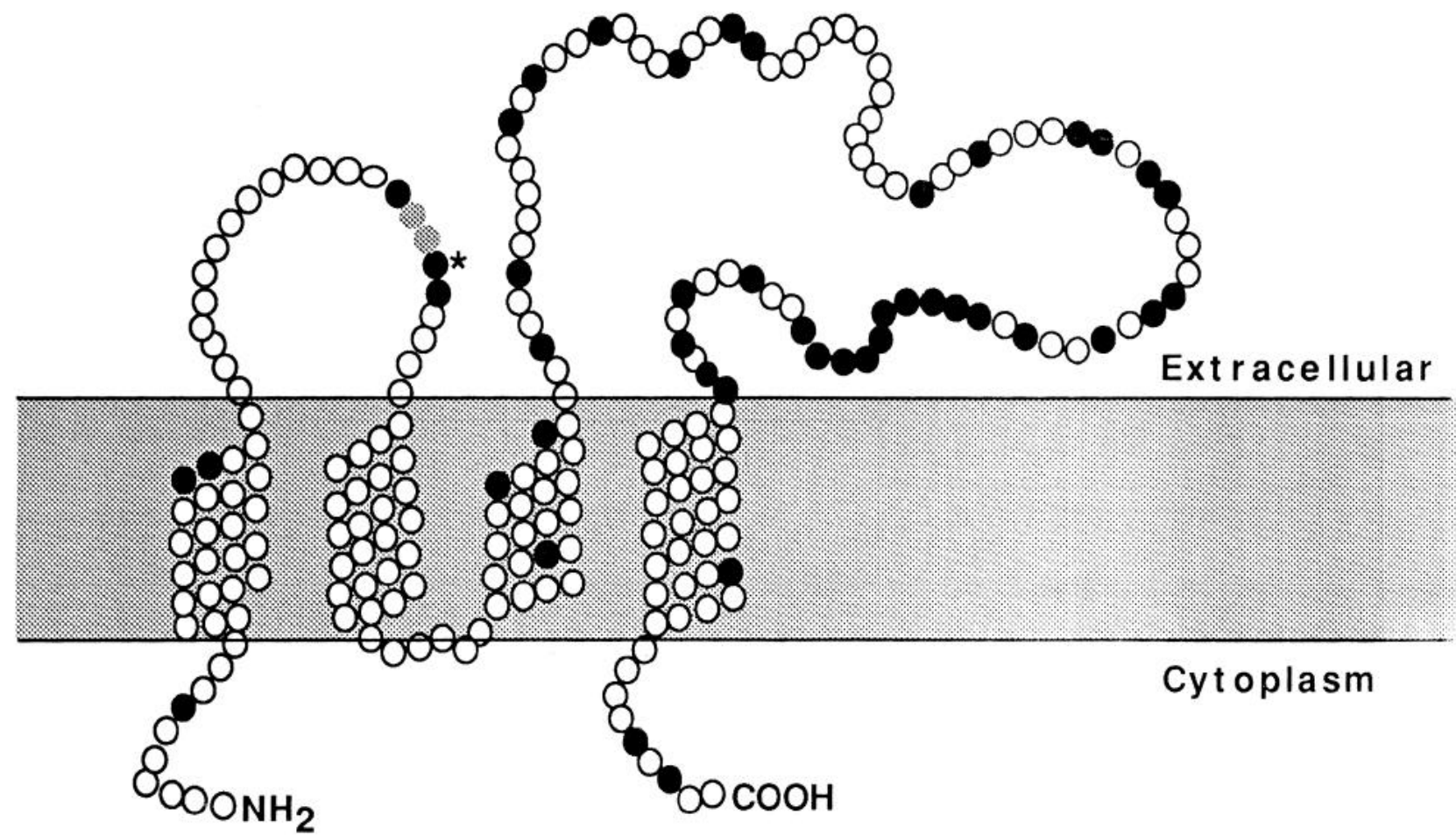


A.

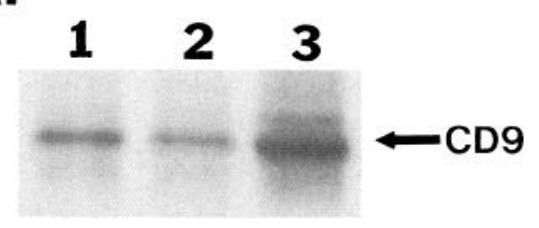

B.

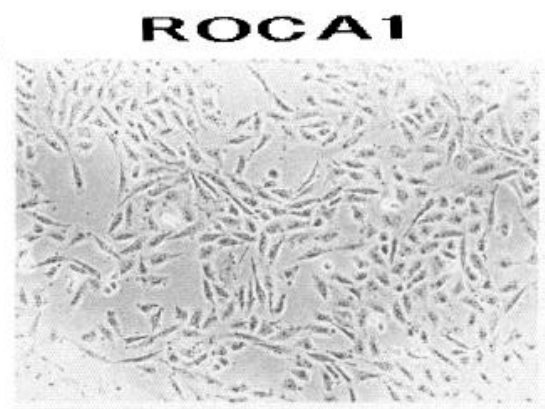

ROCA2

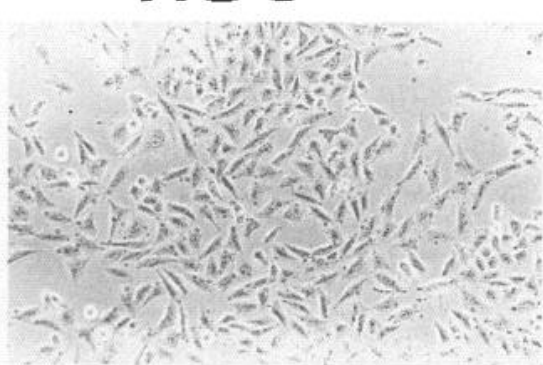

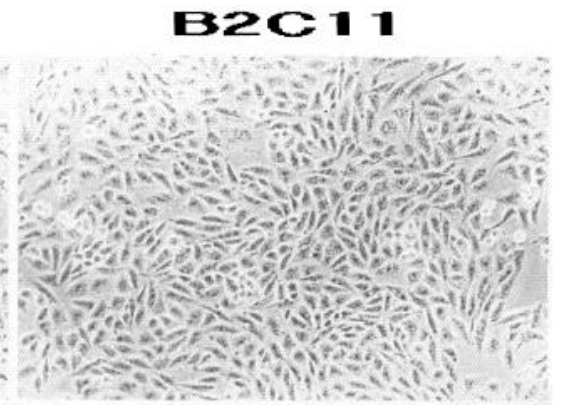
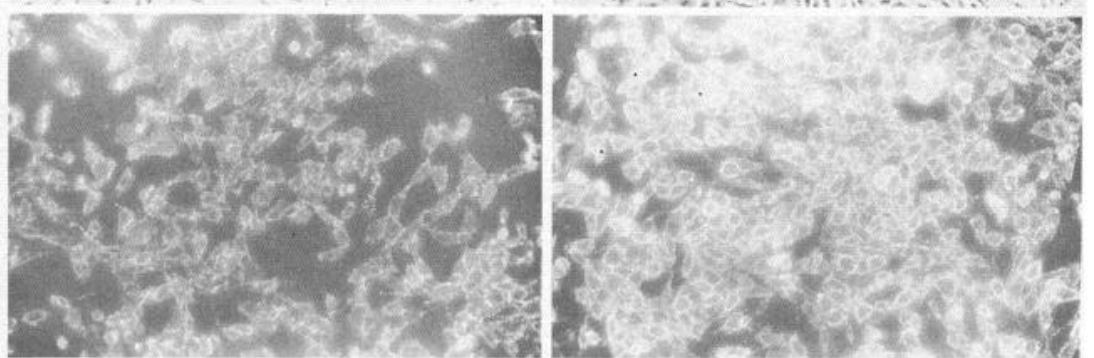

C.

ROCA1

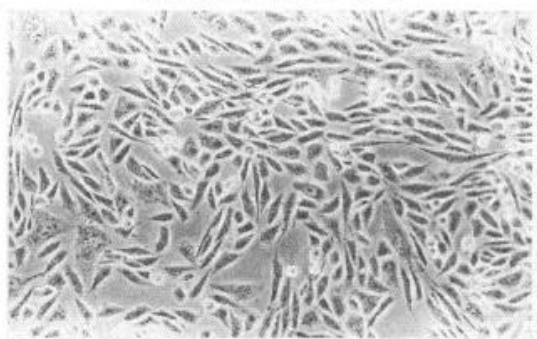

ROCA2

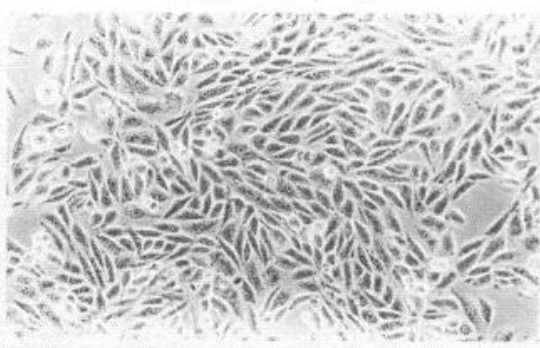

B2C11
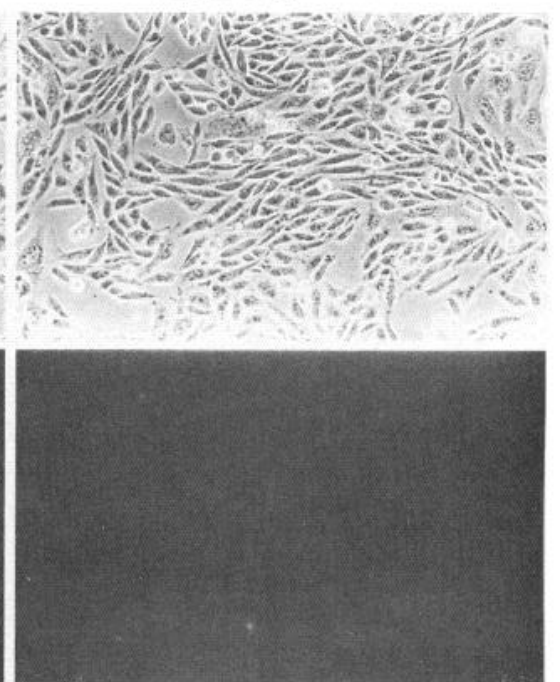

Figure 3. The $26 \mathrm{kDa}$ ROCA cell surface antigen is rat CD9. A, ROCA1 (lane 1), ROCA2 (lane 2), and B2C11 (lane 3) each immunoprecipitate a $26 \mathrm{kDa}$ protein from a $1 \%$ CHAPS extract of ${ }^{35} \mathrm{~S}-$ Met labeled CHO cells that had been stably transfected with the Full ScN. \#13 cDNA, encoding rat CD9. The stably transfected $\mathrm{CHO}$ cell clone used in this particular experiment was CD9 $\gamma$. The arrow indicates the position of CD9 (26 kDa). $B$, ROCA2 and $\mathrm{B} 2 \mathrm{C} 11$, but not ROCA1 label the surfaces of $\mathrm{CD} 9 \gamma$ cells. Live CD9 $\gamma$ cells were sequentially incubated with the various mAbs and a goat anti-mouse IgG fluorescein-conjugated secondary antibody. The top portion of each panel is a phase micrograph, while the bottom portion is a fluorescence micrograph of the same field. $C$, ROCA1, ROCA2, and B2C11 do not label the surfaces of nontransfected CHO cells. Live CHO cells were sequentially incubated with the various $\mathrm{mAbs}$ and a goat anti-mouse IgG fluorescein-conjugated secondary antibody. The top portion of each panel is a phase micrograph, while the bottom portion is a fluorescence micrograph of the same field. 


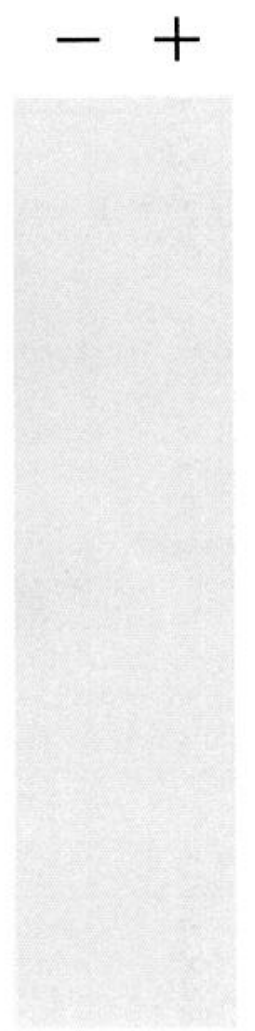

ROCA1

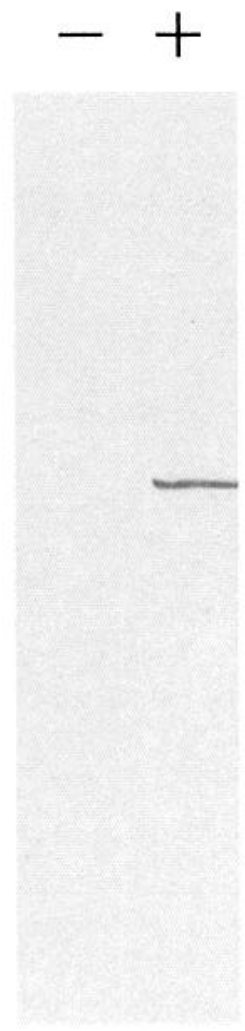

ROCA2

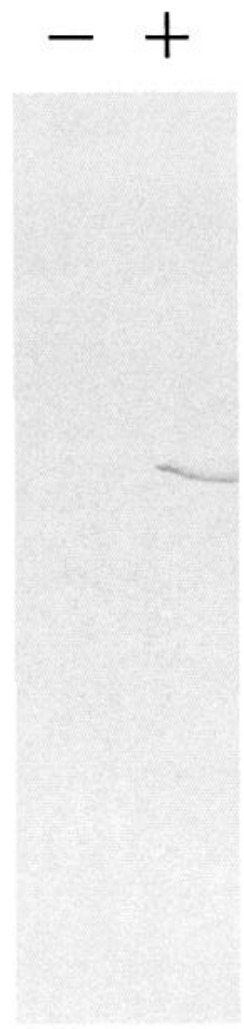

$\mathrm{B} 2 \mathrm{C} 11$

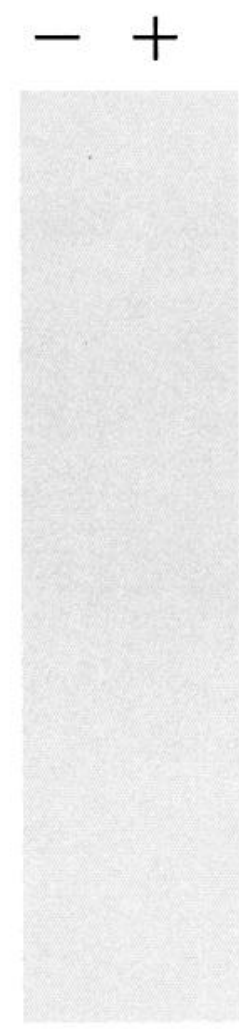

CONTROL
Figure 4. ROCA2 and $\mathrm{B} 2 \mathrm{C} 11$ bind the large, putative extracellular domain of rat CD9. Proteins within extracts generated from E. coli expressing the MBPCD9 fusion protein (+) or MBP (-) were subjected to SDS-PAGE and immunoblot analysis. ROCA2 and $\mathrm{B} 2 \mathrm{C} 11$, but not ROCA1, bind a $49 \mathrm{kDa}$ protein present only in extracts containing the MBP-CD9 fusion protein. Primary antibody binding was visualized with a peroxidase-conjugated goat anti-mouse IgG secondary antibody. The control reflects the binding of the secondary antibody alone. detergent-solubilized membrane/cytoskeletal fractions of adult rat platelets using ROCA1 and ROCA2. We also used mAb B2C11 (Akeson and Warren, 1984) after finding that this mAb binds strongly to the affinity-purified $26 \mathrm{kDa}$ ROCA $1 / 2$ antigen from adult rat peripheral nerves (data not shown; mAb B2C11 is further characterized in the accompanying article; Hadjiargyrou and Patterson, 1994). Each $\mathrm{mAb}$ recognizes a $26 \mathrm{kDa}$ protein in the platelet extract that comigrates with the previously described peripheral nerve protein (Fig. 1). In addition, ROCA2 and $\mathrm{B} 2 \mathrm{C} 11$ each bind larger, glycosylated forms of the $26 \mathrm{kDa}$ protein (Kaprielian and Patterson, 1993) in both platelet and nerve extracts. These results are consistent with the possibility that the $26 \mathrm{kDa}$ ROCA antigen may be rat CD9.

\section{Isolation of rat CD9 $\mathrm{cDNA}$ clones}

To clone the cDNA encoding rat CD9, we used the PCR with nondegenerate oligonucleotide primers corresponding to the $\mathrm{NH}_{2}$-terminal and $\mathrm{COOH}$-terminal sequences of human/bovine CD9. Amplifications were performed using cDNA templates derived from adult rat sciatic nerve or superior cervical sympathetic ganglia mRNA. In both cases, 690 bp products were obtained (data not shown). This corresponds to the expected size for a cDNA clone encoding the entire rat CD9 protein based upon the nucleotide sequences of human and bovine CD9. Two cDNAs obtained using the sciatic nerve $(\mathrm{ScN})$ template, full $\mathrm{ScN \# 13}$ and \#42, as well as two cDNAs obtained using the superior cervical sympathetic ganglia (SCG) template, full SCG\#3 and $\# 8$, were sequenced in both directions (see Materials and Methods), and found to be nearly identical (see Materials and Methods). In addition, we have isolated and characterized three full length cDNAs encoding rat CD9 from a postnatal day 9 rat sciatic nerve cDNA library. The sequences of these clones precisely match those of the PCR products (data not shown).

The rat protein is $95 \%$ identical to mouse CD9, and $93 \%$, $92 \%$, and $83 \%$ identical to the human, monkey, and bovine proteins, respectively (Fig. 2). Rat, mouse, and bovine CD9 each consist of 226 amino acid residues, while human and monkey CD9 are comprised of 228 amino acids. Only rat and mouse CD9 contain a string of seven amino acids between positions 120 and 126, ELQEFYK, which is identical to the sequence of a tryptic peptide generated from the affinity-purified $26 \mathrm{kDa}$ protein (Fig. 2 and Kaprielian and Patterson, 1993). At position 50 in the rat sequence there exists one putative, N-linked glycosylation site (NHS). A similar site is present in the mouse, human, monkey and bovine sequences; each of these sequences, however, possesses additional asparagine residues immediately before the consensus asparagine. Mouse and bovine CD9 contain one, while human and monkey CD9 contain two additional asparagines (Fig. 2). Consistent with previous observations (Rubinstein et al., 1993b), the majority of interspecies amino acid differences in the CD9 protein are present in the large extracellular domain (Fig. 2).

\section{The $26 \mathrm{kDa}$ ROCA antigen is rat CD9}

To confirm the identity of the $26 \mathrm{kDa}$ ROCA antigen, the rat CD9 cDNA clone, full $\mathrm{ScN}$ \#13, was subcloned into the pc$\mathrm{DNAI} /$ neo expression vector (InVitrogen) and introduced into CHO cells. Multiple, stably transfected, clonal $\mathrm{CHO}$ cell lines were isolated through G418 selection. ROCA1, ROCA2, and B2C11 each immunoprecipitate a $26 \mathrm{kDa}$ protein from detergent extracts of such cell lines (Fig. $3 A$ ). Isotype-matched mAbs do not immunoprecipitate CD9 (data not shown). In addition, ROCA 2 and $\mathrm{B} 2 \mathrm{C} 11$, but not ROCA1, strongly and uniformly 


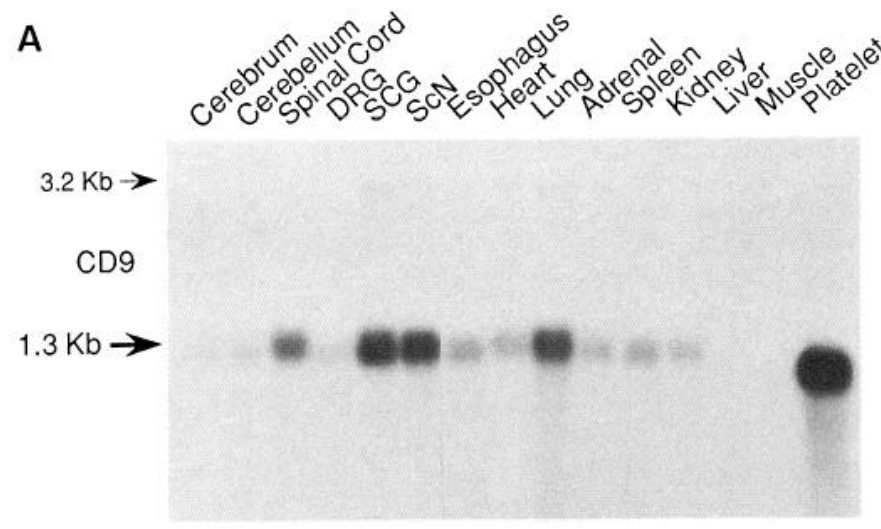

$28 \mathrm{~S}$

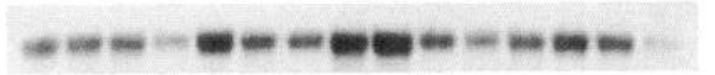

B

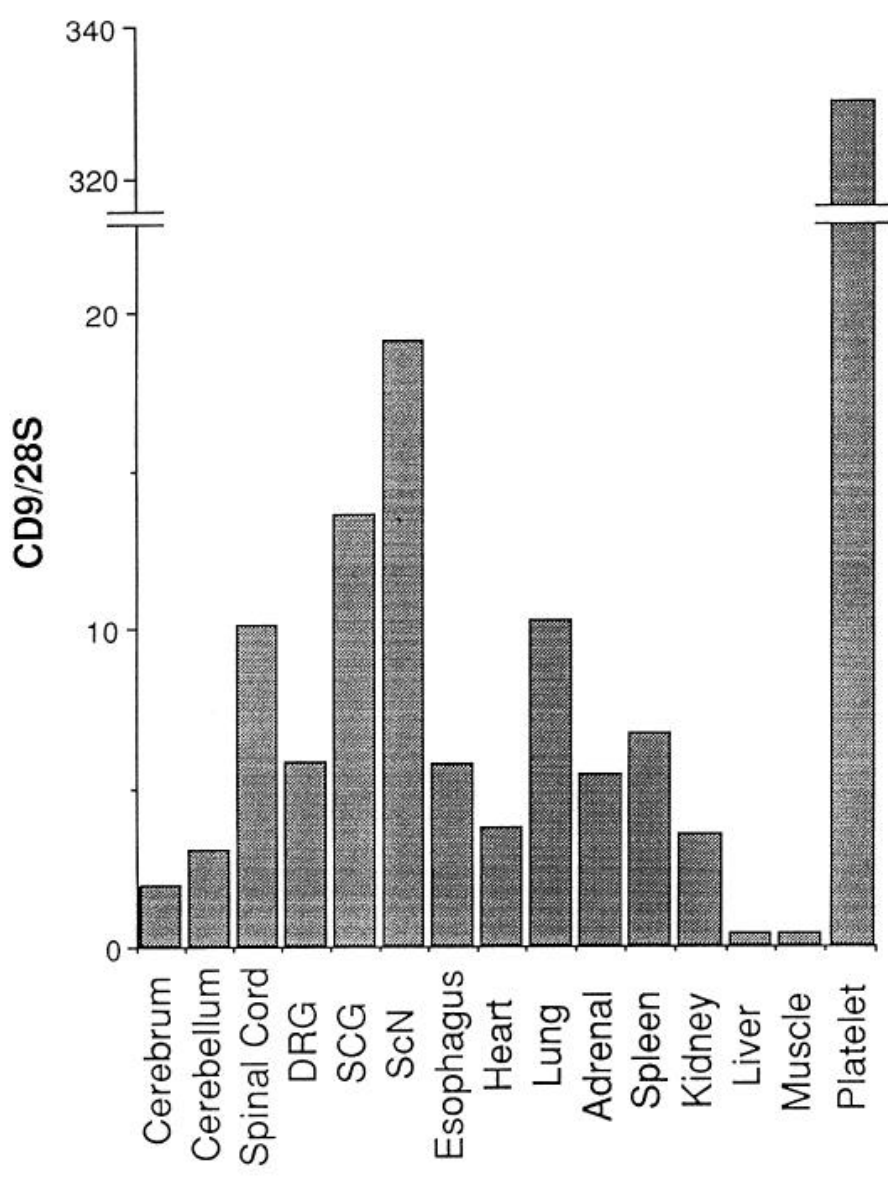

Figure 5. Rat CD9 mRNA is expressed by a wide range of neural and non-neural tissues. $A$, Northern blot analysis was performed using $2 \mu \mathrm{g}$ of total RNA derived from various adult rat tissues and ${ }^{32} \mathrm{P}$-labeled Full $\mathrm{ScN} \# 13$ (rat CD9) and 28S cDNA probes. The top panel shows the hybridization of the rat $\mathrm{CD} 9$ probe to a $1.3 \mathrm{~kb}$ species present in many tissues, and the bottom panel shows the hybridization of the $28 \mathrm{~S}$ probe to all tissues. The apparent size difference between platelet CD9 mRNA and CD9 mRNAs in other tissues is due to frowning of this particular gel and the placement of the platelet lane at the extreme edge of the gel. $B$, The radioactivity in all lanes was quantified using a Phosphorimager, and plotted as the ratio of CD9 mRNA to $28 \mathrm{~S}$ rRNA versus tissue type. label the surfaces of these same cells (Fig. 3B). None of our antirat CD9 mAbs bind the surfaces of (Fig. $3 C$ ), or immunoprecipitate any protein from (data not shown), the mock-transfected CHO cells (Fig. 3C).

To prove that ROCA 2 and $\mathrm{B} 2 \mathrm{C} 11$ recognize the large, putative extracellular domain of CD9, we generated a fusion protein (see Materials and Methods) containing residues 111-190 of rat CD9. Consistent with the fact that ROCA2 and $\mathrm{B} 2 \mathrm{C} 11$ bind living cells expressing the entire rat CD9 protein, ROCA2 and $\mathrm{B} 2 \mathrm{C} 11$, but not ROCA1, bind this fusion protein (Fig. 4).

\section{Expression of rat CD9 $m R N A$}

Tissue distribution. Northern blot analysis was performed using total RNA from various adult rat tissues and the full $\mathrm{ScN}$ \#13 rat CD9 cDNA probe. This probe identifies a $1.3 \mathrm{~kb}$ RNA band in a wide range of tissues (Fig. $5 A$ ). For each tissue, the ratio of CD9 mRNA to 28S rRNA was calculated (Fig. 5B). Based upon this analysis, adult rat platelets are the most abundant source of CD9 mRNA. This is consistent with the known distribution of CD9 in other species. Superior cervical ganglia (SCG), sciatic nerve $(\mathrm{ScN})$ and spinal cord all express high levels of CD9 mRNA. Low, but clearly detectable levels are present in dorsal root ganglia (DRG) and cerebellum, but very little signal is detected in the cerebrum. While significant levels of CD9 mRNA are present in a number of non-neural tissues such as esophagus, heart, lung, adrenal, spleen, and kidney, no hybridization was observed to liver or skeletal muscle RNA. The rat CD9 probe also hybridizes to a minor, $3.2 \mathrm{~kb}$ species in superior cervical ganglia and sciatic nerve RNA (Fig. $5 A$; see Discussion).

Cell type specific expression. In situ hybridization studies were performed to unambiguously determine whether neurons as well as glia express CD9 mRNA. Digoxygenin-labeled antisense and sense RNA probes derived from the full ScN \#13 cDNA were hybridized to sections of selected neural and non-neural tissues. The cytoplasm of adult rat SCG and DRG neurons is clearly labeled by the antisense probe (Fig. $6 a, c$ ). While most of the neurons present within SCG sections are labeled by the rat CD9 probe, only a small subset of DRG neurons detectably express CD9 mRNA. This finding is consistent with a significantly lower level of CD9 mRNA in the DRG as compared to the SCG, as determined by Northern analysis. Schwann cells present within sections of adult rat peripheral nerve also clearly express CD9 mRNA (Fig. 6b). The identification of these cells as Schwann cells is based upon (1) labeling of very similar appearing cells using Po and MBP RNA probes (data not shown), (2) the bipolar, longitudinal morphology of the labelled cells, and (3) the large number of CD9 ${ }^{+}$cells. In addition, the cytoplasm of chromaffin cells in the adrenal medulla (Fig. $6 d$ ) and epithelial cells in the esophagus (data not shown) strongly label with the antisense CD9 probe. In all cases, no hybridization was detected with the sense probe (data not shown).

Positional and developmental expression. We also examined the rostrocaudal distribution of CD9 mRNA. Northern analysis detects essentially equivalent levels of the $1.3 \mathrm{~kb}$ CD9 mRNA (normalized to the amount of myelin basic protein (MBP) mRNA) in adult rat intercostal nerves taken from various rostrocaudal levels (Fig. 7). Similarly, the number of Schwann cells expressing rat CD9 $\mathrm{mRNA}$ does not appear to vary significantly between rostral and caudal nerves (data not shown).

Northern and in situ analyses were also used to determine if CD9 mRNA expression is developmentally regulated in postnatal rat ScNs. We performed similar analyses with probes spe- 

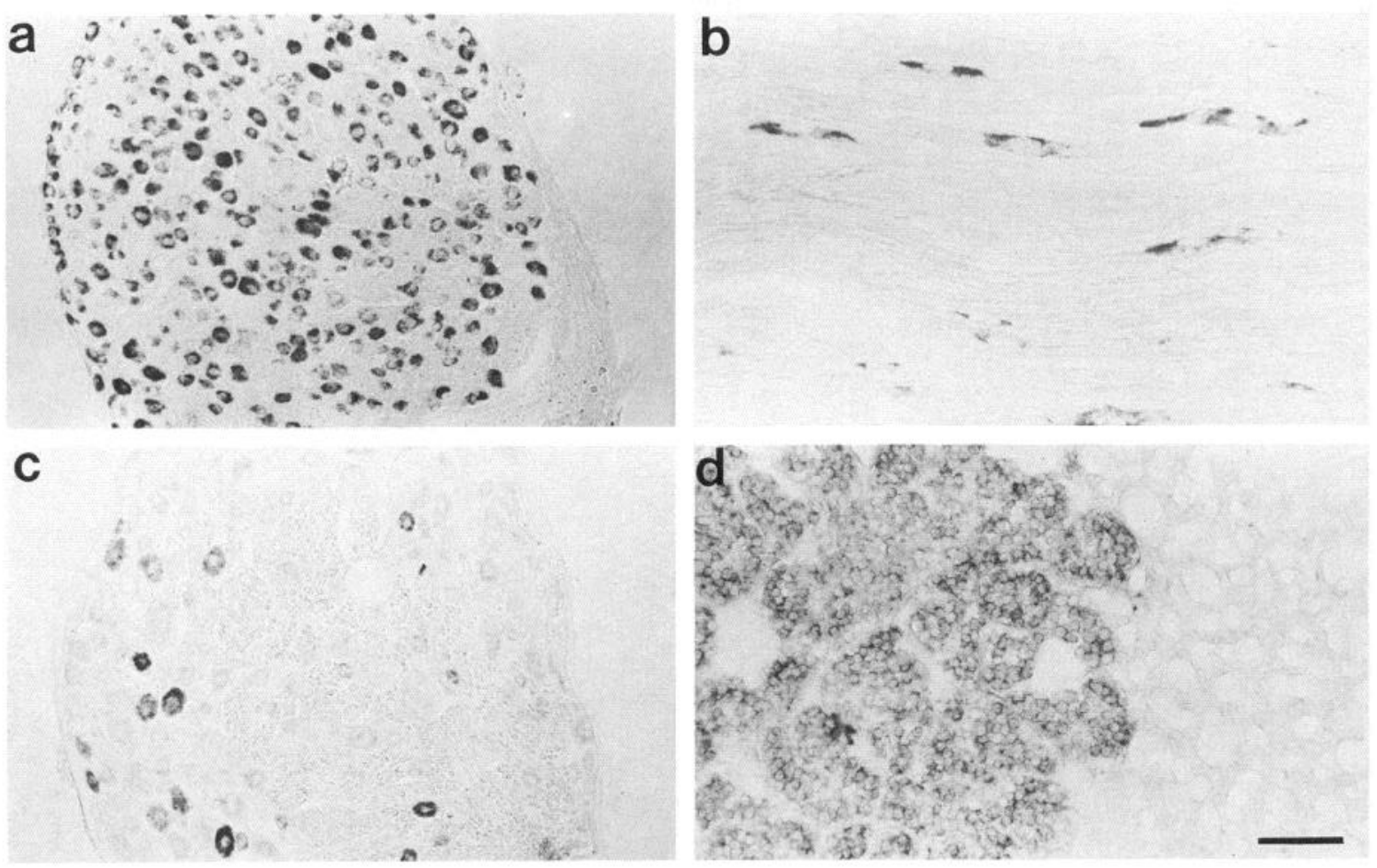

Figure 6. Rat CD9 mRNA is expressed by peripheral neurons, Schwann cells and chromaffin cells. Digoxygenin-labeled antisense RNA probes derived from the Full ScN \#13 cDNA were hybridized to cryosections of adult rat SCG $(a)$, sciatic nerve $(b)$, DRG $(c)$, and adrenal gland $(d)$. The cytoplasm of neurons present within the SCG and DRG sections $(a, c)$ and bipolar Schwann cells in the sciatic nerve section $(b)$ are all brightly labeled. The left portion of the adrenal gland section $(d)$ contains strongly labeled chromaffin cells of the adrenal medulla, while the right portion shows the unlabeled cortex.

cific for Po and MBP, two myelin genes whose expression is known to be developmentally regulated in these nerves (Wiggins et al., 1975; Lees and Brostoff, 1984; Lemke and Axel, 1985; Stahl et al., 1990). Northern analysis shows that the mRNA expression of all three genes dramatically rises from a low, but clearly detectable level in newborn sciatic nerves, to maximum levels by postnatal day 14 (Fig. $8 A$ ). By day $60, \mathrm{CD} 9, \mathrm{MBP}$, and Po mRNA expression is downregulated to adult levels. In situ hybridization performed with the full $\mathrm{ScN} \# 13 \mathrm{CD} 9$ antisense probe confirms these results. While only a small number of scattered Schwann cells express CD9 mRNA in the newborn $\mathrm{ScN}$, large numbers are strongly labeled by postnatal days 7 and 14 (Fig. 8B). By day 60, the number of labeled Schwann cells is reduced to adult levels. Similar results were obtained with a MBP antisense probe (data not shown).

\section{Discussion}

We previously generated the mAb, ROCAl, which recognizes an epitope on a $26 \mathrm{kDa}$ cell surface protein that is preferentially accessible in rostral intercostal nerves and rostral sympathetic ganglia (Suzue et al., 1990; Kaprielian and Patterson, 1993). Two other mAbs, ROCA2 and $\mathrm{B} 2 \mathrm{C} 11$, also recognize the 26 $\mathrm{kDa}$ protein, but do not detect a rostrocaudal, immunohistochemical gradient. Amino acid sequences obtained from the affinity-purified protein suggested that it could be the rat homolog of CD9 (Kaprielian and Patterson, 1993). We present here the isolation of cDNA clones encoding rat $\mathrm{CD} 9$ from peripheral nerves and ganglia, and demonstrate that the ROCA cell surface protein is, in fact, rat $\mathrm{CD} 9$. We also show that rat CD9 mRNA is expressed at high levels in peripheral neurons

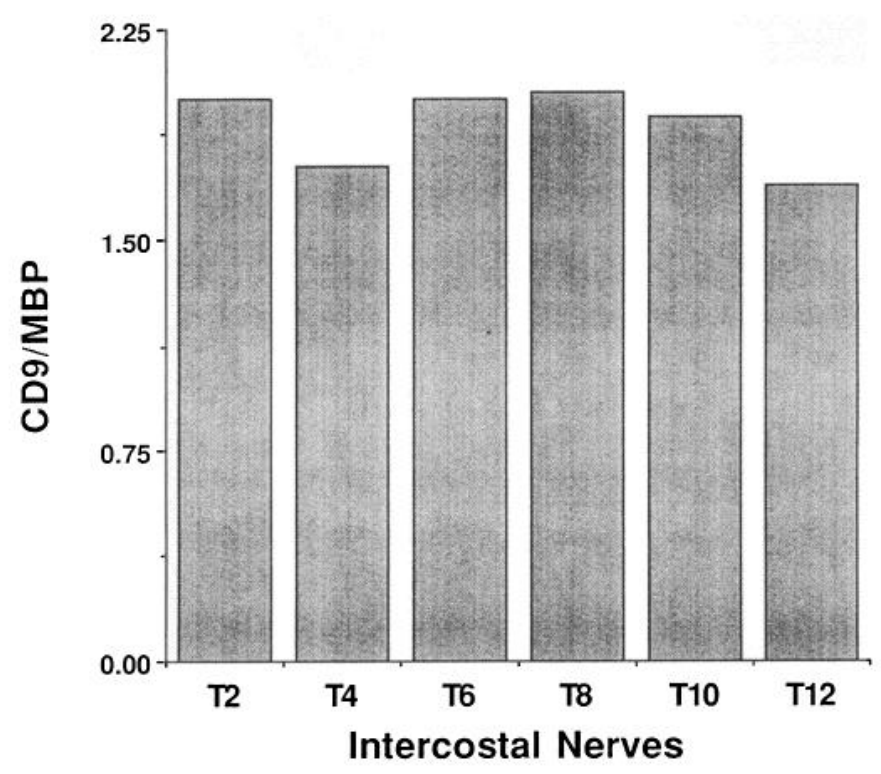

Figure 7. The expression of rat CD9 mRNA is not graded along the rostrocaudal axis. Northern blot analysis was performed using $2 \mu \mathrm{g}$ of total RNA derived from adult rat intercostal nerves taken from various rostrocaudal levels, and ${ }^{32} \mathrm{P}$-labeled Full $\mathrm{ScN} \# 13$ (rat CD9) and MBP cDNA probes. The identical transfer was probed with each cDNA in succession after removal of previously bound radioactivity. The radioactivity representing the hybridization of each probe was quantified using a Phosphorimager and the ratio of CD9 mRNA to MBP mRNA plotted versus rostrocaudal position. 
and Schwann cells, as well as in certain parts of the central nervous system. In addition, we demonstrate that while CD9 mRNA is not positionally regulated in intercostal nerves, it is coordinately regulated with myelin genes during postnatal $\mathrm{ScN}$ development.

\section{The ROCA cell surface $26 \mathrm{kDa}$ protein is rat $C D 9$}

Using the PCR, as well as direct cDNA library screening, we obtained cDNA clones representing the probable entire coding region of rat $\mathrm{CD} 9$ from $\mathrm{SCG}$ and $\mathrm{ScN}$. The high degree of amino acid identity between the deduced protein sequence of the rat form and the mouse (95\%), human (93\%), monkey $(92 \%)$, and bovine $(83 \%)$ forms strongly supports the identification of these cDNAs as rat CD9. Our CD9 $\mathrm{mAbs}$ bind the cell surface and fail to cross-react across species. The larger, putative extracellular loop that contains the majority of interspecies amino acid differences (Martin-Alonso et al., 1992; Reynolds et al., 1992; Wright et al., 1993), also contains the epitopes recognized by ROCA2 and $\mathrm{B} 2 \mathrm{Cl} 1$, as shown by positive binding to immunoblots of a fusion protein containing residues $111-190$ of the rat protein. Interestingly, ROCA1 does not bind this fusion protein, even though it binds the full-length protein very well (Fig. $3 A$ ). This result, coupled with the finding that ROCAl can bind to the complete fusion protein on immunoblots and to intact primary cells, suggests that the position-dependent ROCA 1 epitope resides on the smaller extracellular loop (residues 3655) of CD9.

The deduced rat CD9 protein sequence contains the same string of seven amino acids, ELQEFYK, as one of the tryptic peptides generated from the affinity purified $26 \mathrm{kDa}$ protein (Kaprielian and Patterson, 1993). The N-terminal 14 amino acids (deduced from the cDNA) of the rat protein, PVKGGSKCIKYLLF, are similar to those obtained by sequencing the $\mathrm{N}$-terminus of the affinity-purified $\mathrm{ScN}$ protein, XVKGGIDEVFYLLF (Kaprielian and Patterson, 1993). All 12 of the rat $\mathrm{CD} 9$ cDNAs, contain the amino acid string, SKCIK, not IDEVF, between positions 6 and 10 within this string. This discrepancy may be duc to protein sequencing errors or to the existence of two forms of rat CD9 with different $\mathrm{N}$-terminal sequences. Support for the protein sequencing error explanation comes from previous attempts to sequence the $\mathrm{N}$-terminus of human CD9; three different groups failed to unambiguously determine the identity of all five residues (Higashara et al., 1990; Boucheix et al., 1991; Lanza et al., 1991).

We performed additional $P C R$ reactions to search for a form of CD9 containing the amino acid string IDEVF from amino acid position 7 to 11 . Sequence analysis of 23 distinct clones identified either the same form of rat CD9 that we report here (N-terminus: MPVKGGSKCIK) or nonsense sequences (data not shown). Despite these results, however, we cannot rule out the existence of another, perhaps alternatively spliced, form of rat CD9.

Immunoprecipitation of a $26 \mathrm{kDa}$ protein by ROCA 1, ROCA2, and $\mathrm{B} 2 \mathrm{C} 11$ from detergent extracts of $\mathrm{CHO}$ cells stably transfected with a rat CD9 cDNA confirms the identity of the ROCA cell surface antigen as CD9. Interestingly, ROCA1, unlike ROCA2 and B2C11, does not label the surfaces of the transfected cells. ROCA1 does not bind the surface of a variety of other cell types that are strongly labeled with ROCA2 and B2C11 (Hadjiargyrou and Patterson, 1994, and unpublished observations), but does bind to the surfaces of primary Schwann cells (Tole, unpublished observations). Together with our previous

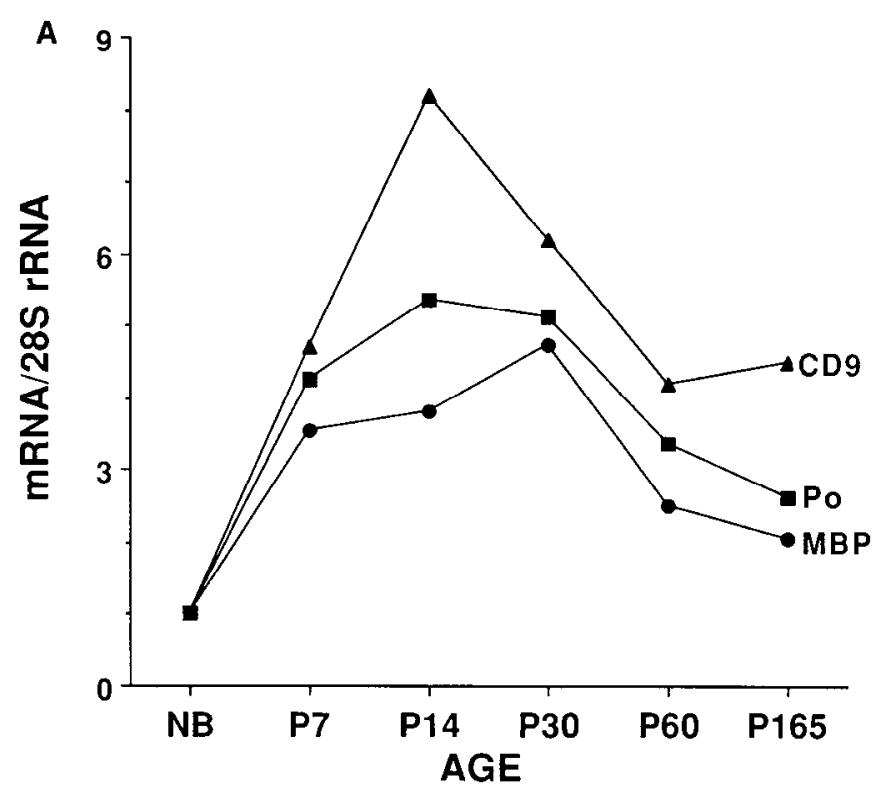

Figure 8. The expression of rat CD9 mRNA is developmentally regulated in postnatal sciatic nerves. $A$, Northern blot analysis was performed using $2 \mu \mathrm{g}$ of total RNA derived from sciatic nerves taken from postnatal rats of various ages, and ${ }^{32}$ P-labeled Full ScN \#13 (rat CD9), MBP, Po, and 28S cDNA probes. The identical transfer was probed with each cDNA in succession after removal of previously-bound radioactivity. The radioactivity representing the hybridization of each probe was quantified using a Phosphorimager and the ratio of the various mRNAs to $28 \mathrm{~S}$ rRNA plotted versus developmental age. $B$, Digoxygenin-labeled antisense RNA probes derived from the Full ScN \#13 cDNA were hybridized to cryosections of developing postnatal rat sciatic nerves. The number of Schwann cells expressing rat CD9 significantly increases by postnatal day 7 , and then decreases to adult levels by postnatal day 60 .

in vivo observations (Kaprielian and Patterson, 1993), these results suggest that the ROCAl epitope may not always exist in an accessible state on the cell surface. In this regard, the transfected $\mathrm{CHO}$ cells may represent a model system for further study of epitope masking on CD9.

\section{Expression of rat $C D 9 \mathrm{mRNA}$}

Tissue and cell type specific expression. We detect a major 1.3 $\mathrm{kb}$ band of rat CD9 mRNA in many, but not all adult tissues. Of the tissues examined, only liver and skeletal muscle contain no detectable rat CD9 mRNA. The significant levels of CD9 mRNA present in certain neural tissues, including adult rat peripheral nerves and ganglia, spinal cord, and cerebellum, are consistent with the isolation of rat CD9 $\mathrm{cDNAs}$ from adult SCG and ScN DNA templates. Other studies have identified a similar size mRNA band in Northern blots using CD9 cDNA probes (Boucheix et al., 1991; Martin-Alonso et al., 1992). However, an extensive analysis of CD9 mRNA tissue distribution has not previously been described. The rat CD9 probe also hybridized weakly to a $3.2 \mathrm{~kb}$ mRNA band. While the nature of this species is not known, this band is present in a wide variety of tissues and cell lines (data not shown).

In situ hybridization shows that peripheral neurons, glia and chromaffin cells express rat CD9 mRNA. In particular, neurons in SCG and DRG, Schwann cells in ScNs, and chromaffin cells in the adrenal medulla are all strongly labeled by the CD9 antisense probe. Neuronal labcling is clcarly detcctable in carly postnatal sympathetic and sensory ganglia (data not shown) and 
B
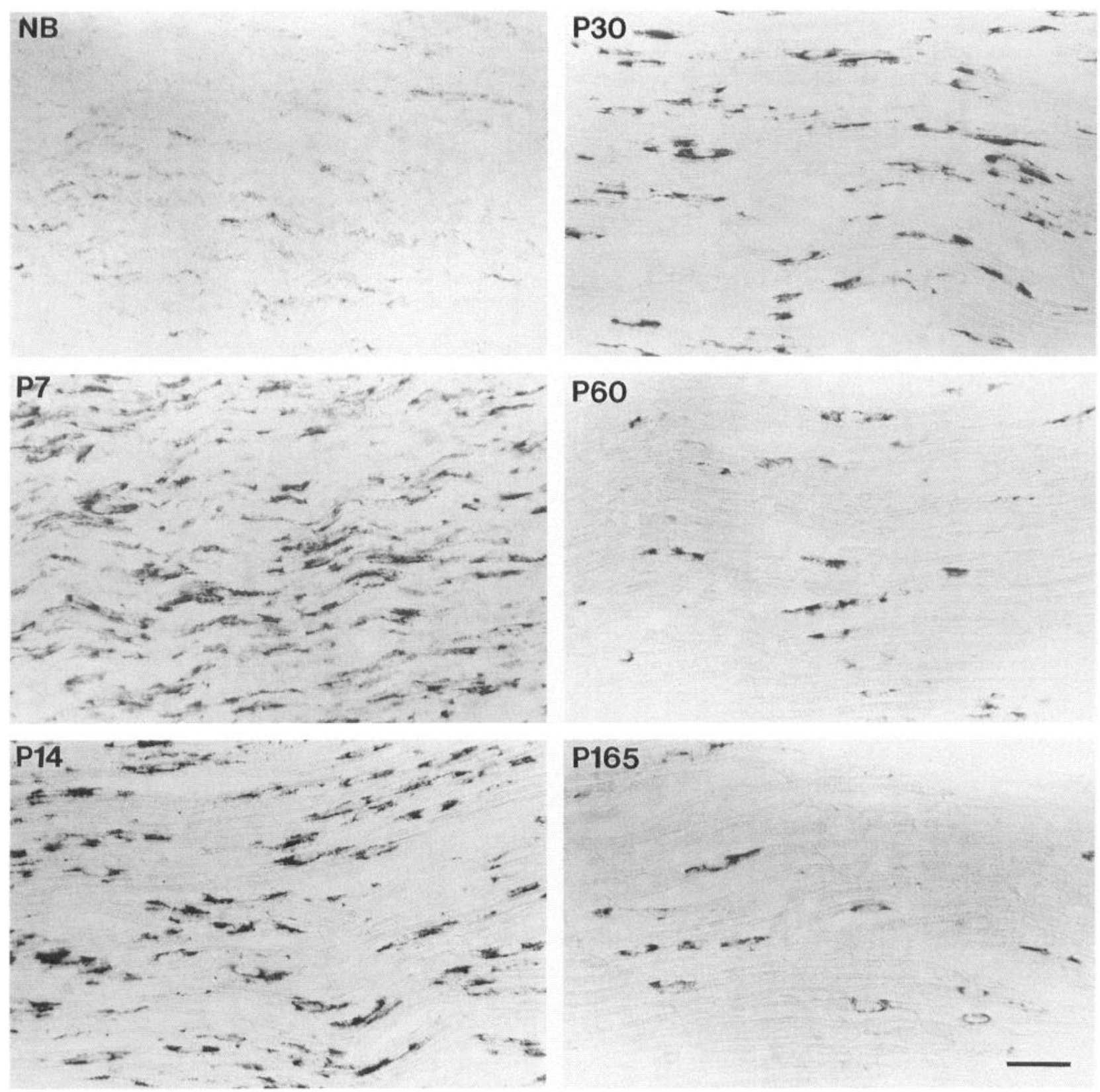

Figure 8. continued.

is maintained into adulthood. We have previously shown that satellite cells in sections of adult SCG are DRG are labeled by ROCA1 and 2 (Suzue et al., 1990; Kaprielian and Patterson, 1993; Tole and Patterson, 1993), as well as B2C11 (unpublished observations). We cannot, however, unambiguously detect label in the cytoplasm of ganglionic satellite cells in our in situ analysis. This may reflect the presence of lower levels of CD9 mRNA in satellite cells than in neurons. Taken together, the northern blot and in situ hybridization results confirm and extend previous immunoblot and immunohistochemical analyses demonstrating that rat peripheral neurons, Schwann cells, and chromaffin cells all express CD9 (Kaprielian and Patterson, 1993; Tole and Patterson, 1993). To our knowledge, this is the first study utilizing in situ hybridization to localize CD9 mRNA in any tissue.

Positional and developmental expression. Northern blot analysis shows that equivalent levels of CD9 mRNA are present in rostral and caudal intercostal nerves. This result is consistent with previous immunoblot analyses demonstrating that both ROCA1 and ROCA2, as well as B2C11 (Z. Kaprielian, unpublished observations), detect uniform levels of the $26 \mathrm{kDa}$, rat CD9 protein in rostral and caudal intercostal nerves (Kaprielian and Patterson, 1993). These findings all support the notion that ROCA1 binding reflects the presence of a positionally graded epitope, rather than a rostrocaudal gradient of $\mathrm{CD} 9$ protein. Of course, the formal possibility remains, that ROCAl recognizes 
an as yet unidentified third antigen (in addition to CD9 and peripherin) whose distribution may directly account for the immunohistochemical gradient.

Northern blot and in situ hybridization analyses shows that the expression of CD9 mRNA is significantly upregulated during early postnatal SCN development, and downregulated in the adult. This time course suggests that CD9 and peripheral myelin gene expression (Wiggins et al., 1975; Lees and Brostoff, 1984; Lemke and Axel, 1985; Stahl et al., 1990) are coordinately regulated during postnatal development. Together with the expression of the CD9 protein on neuronal as well as Schwann cell surfaces, these developmental data further suggest a role for CD9 in mediating Schwann cell-axon interactions during myelination. Moreover, the results of antibody perturbation experiments strongly suggest a role for CD9 in neural cell adhesion (Hadjiargyrou and Patterson, 1994).

Interestingly, the developmental expression of CD9 also parallels that of another peripheral myelin gene PMP-22 (Welcher et al., 1991; Snipes et al., 1992). PMP-22 is the target of mutations that result in the trembler phenotype in mice and in Charcot-Marie-Tooth disease (CMT) Type la in humans (Snipes et al., 1993). Although PMP-22 bears no sequence homology with members of the CD9 tetraspan family, this protein has also been implicated in growth regulation and possesses four putative membrane-spanning domains (Lemke, 1993; Snipes et al., 1993; Suter et al., 1993). In this regard, it is interesting to note that another four transmembrane spanning domain molecule, connexin 32 (Cx32), has recently been shown, like MBP, P0, and PMP-22, to be downregulated in transected sciatic nerves (S. Scherer, personal communication). Moreover, patients with $\mathrm{X}$-linked CMT possess mutations in the genc cncoding $\mathrm{C} \times 32$ (Bergoffen et al., 1993). Thus, it seems possible that proteins containing the four transmembrane domain structural motif may play important roles in peripheral nerve myelination.

\section{References}

Akeson R, Warren SL (1984) Detection of a cell surface antigen found on rat peripheral nervous system neurons and multiple glia: astrocytes, oligodendrocytes, and Schwann cells. J Neurosci Res 12:4157.

Amiot M (1990) Identification and analysis of cDNA clones encoding CD53. A pan-leucocyte antigen related to membrane transport proteins. J Immunol 145:4322-4325.

Andria ML, Hsieh C, Oren R, Francke U, Levy S (1991) Genomic organization and chromosomal localization of the TAPA-1 gene. $\mathbf{J}$ İmmunol 147:1030-1036.

Angelisova P, Vlcek C, Stefanova I, Lipoldova M, Horejsi V (1990) The leukocyte surface antigen CD53 is a protein structurally similar to the $\mathrm{CD} 37$ and MRC OX-44 antigens. Immunogenetics 32:281285.

Anton ES, Hadjiargyrou M, Patterson PH, Matthew WD (1995) CD9 plays a role in Schwann cell migration in vitro. J Neurosci 15:584595.

Bellacosa A, Lazo PA, Bear SA, Tsichlis PN (1991) The rat leukocyte antigen MRC OX-44 is a member of a new family of cell surface proteins which appear to be involved in growth regulation. Mol Cell Biol 11:2864-2872.

Bergoffen J, Scherer SS, Wang S, Oronzi Scott M, Bone LJ, Paul DL, Chen K, Lensch MW, Chance PF, Fischbeck KH (1993) Connexin mutations in X-linked Charcot-Marie-Tooth disease. Science 262: 2039-2042.

Birren SJ, Lo LC, Anderson DJ (1993) Sympathetic neurons undergo a developmental switch in trophic dependence. Development 119: 597-610.

Boucheix C, Soria C, Mirshahi M, Soria J, Perrot JY, Fournier N, Billard $M$, Rosenfeld C (1983) Characteristics of platelet aggregation induced by the monoclonal antibody $\mathrm{ALB}_{6}$ (acute lymphoblastic leu- kemia antigen $\mathrm{p}$ 24). Inhibition of aggregation by $\mathrm{ALB}_{6}$ Fab. FEBS Lett 161:289-295.

Boucheix C, Benoit P, Frachet P, Billard M, Worthington RE, Gagnon J, Uzan G (1991) Molecular cloning of the CD9 antigen. J Biol Chem 266:117-122.

Cho KO, Wall JB, Pugh PC, Ito M, Mueller SA, Kennedy MB (1991) The a subunit of Type II $\mathrm{Ca}^{2+} /$ Calmodulin-dependent protein kinase is highly conserved in Drosophila. Neuron 7:439-450.

Choi YC (1985) Structural organization of ribosomal RNAs from Novikoff hepatoma II: characterization of possible binding sites of 5S rRNA and 5.8S rRNa to 28S rRNA. J Biol Chem 260:1277312779.

Chomczynski P, Sacchi N (1987) Single-step method of RNA isolation by acid guanidinium thiocyanate-phenol-chloroform extraction. Anal Biochem 162:156-159.

Classon BJ, Williams AF, Willis AC, Seed B, Stamenkovic I (1989) The primary structure of the human leukocyte antigen CD37, a species homologue of the rat MRC OX-44 antigen. J Exp Med 169:14971502.

Davern KM, Wright MD, Herrmann VR, Mitchell GF (1991) Further characterization of the Schistosoma japonicum protein $\mathrm{Sj} 23$ that is a target of an immunodiagnostic monoclonal antibody. Mol Biochem Parasitol 48:67-76.

Emi N, Kitaori K, Seto M, Ueda R, Saito H, Takahashi T (1993) Isolation of a novel cDNA clone showing marked similarity to ME491/ CD63 superfamily. Immunogenetics 37:193-198.

Feinberg AP, Vogelstein B (1983) A technique for radiolabeling DNA restriction endonuclease fragments to high specific activity. Anal Biochem 132:6-13.

Felgner PL, Gader TR, Holm M, Roman R, Chan HW, Wenz M, Northrop JP, Ringold GM, Danielsen M (1987) Lipofection: a highly efficient lipid-mediated DNA-transfection procedure. Proc Natl Acad Sci USA 84:7413-7417.

Forsyth KD (1991) Anti-CD9 antibodies augment neutrophil adherence to endothelium. Immunology 72:292-296.

Gaugitsch HW, Hofer E, Huber NE, Schnabl E, Baumruker T (1991) A new superfamily of lymphoid and melanoma cell proteins with extensive homology to Schistosoma mansoni antigen $\mathbf{S m} 23$. Eur $\mathbf{J}$ Immunol 21:377-383.

Gil ML, Vita N, Lebel-Binay S, Miloux B, Chalon P, Kaghad M, Marchiol-Fournigault C, Conjeaud H, Caput D, Ferrara P, Fradelizi D, Quillet-Mary A (1992) A member of the tetraspans transmembrane protein superfamily is recognized by a monoclonal antibody raised against an HLA class I-deficient, lymphokine-activated killer-susceptible, B lymphocyte line. Cloning and preliminary functional studies. J Immunol 148:2826-2833.

Griffith L, Slupsky J, Seehafer J, Boshkov L, Shaw ARE (1991) Platelet activation by immobilized monoclonal antibody: evidence for a CD9 proximal signal. Blood 78:1753-1759.

Hadjiargyrou M, Patterson PH (1995) An anti-CD9 monoclonal antibody promotes adhesion and induces proliferation of Schwann cells in vitro. J Neurosci 15:574-583.

Harland RM (1991) In situ hybridization: an improved whole mount method forXenopus embryos. In: Methods in cell biology (Kay BK, Peng HJ, eds), pp 675-685. New York: Academic.

Higashara M, Takahata K, Yatomi Y, Nakahara K, Kurokawa K (1990) Purification and partial characterization of $\mathrm{CD} 9$ antigen of human platelets. FEBS Lett 264:270-274.

Horejsi V, Vlcek C (1991) Novel structurally distinct family of leucocyte surface glycoproteins including CD9, CD37, CD53 and CD63. FEBS Lett 288:1-4.

Hotta H, Ross AH, Huebner K, Isobe M, Wendenborn S, Chao MV, Ricciardi RP, Tsujimoto Y, Croce CM, Koprowski H (1988) Molecular cloning and characterization of an antigen associated with early stages of melanoma tumor progression. Cancer Res 48:2955-2962.

Hynes RO, Lander AD (1992) Contact and adhesive specificities in the associations, migrations, and targeting of cells and axons. Cell 68 : 303-322.

Ikeyama S, Koyama M, Yamaoko M, Sasada R, Miyake M (1993) Suppression of cell motility and metastasis by transfection with human motility-related protein (MRP-1/C.D9) DNA. J Exp Med 177: 1231-1237.

Imai T, Fukudome K, Takagi S, Nagira M, Furuse M, Fukuhara N, Nishimura M, Hinuma Y, Yoshie O (1992) C33 antigen recognized by monoclonal antibodies inhibitory to human $\mathrm{T}$ cell leukemia virus 
type 1-induced syncytium formation is a member of a new family of transmembrane proteins including CD9, CD37, CD53 and CD63. J Immunol 149:2879-2886.

Jennings LK, Fox CF, Kouns WC, McKay CP, Ballou LR, Schultz HE (1990) The activation of human platelets mediated by anti-human platelet p24/CD9 monoclonal antibodies. J Biol Chem 265:38153822.

Kallin B, de Martin R, Etzold T, Sorrentino V, Philipson L (1991) Cloning of a growth arrest-specific and transforming growth factor $b-$ regulated gene, TI 1, from a epithelial cell line. Mol Cell Biol 10: 5338-5345.

Kaprielian Z, Patterson PH (1993) Surface and cytoskeletal markers of rostrocaudal position in the mammalian nervous system. J Neurosci 13:2495-2508.

Kemshead JT, Fritschy J, Asser U, Sutherland R, Greaves MF (1982) Monoclonal antibodies defining markers with apparent selectivity for particular haematopoietic cell types may also detect antigens on cells of neural crest origin. Hybridoma 1:109-123.

Komada Y, Peiper SC, Melvin SL, Metzgar DW, Tarnowski BH, Green AA (1983) A monoclonal antibody (SJ-9A4) to p24 present on alls, neuroblastomas and platelets. I. Characterization and development of a unique radioimmunometric assay. Leuk Res 7:487-498.

Lanza F, Wolf D, Fox CF, Kieffer N, Seyer JM, Fried VA, Coughlin SR, Phillips DR, Jennings LK (1991) CDNA cloning and expression of platelet p24/CD9. J Biol Chem 266:10638-10645.

Lees MB, Brostoff SW (1984) Proteins of myelin. In: Myelin (Morell P, ed), pp 197-224. New York: Plenum.

Lemke $G$ (1993) The molecular genetics of myelination: an update. Glia 7:263-271.

Lemke G, Axel R (1985) Isolation and sequence of a cDNA encoding the major structural protein of peripheral myelin. Cell 40:501-508.

Levy S, Nguyen VQ, Andria ML, Takahashi S (1991) Structure and membrane topology of TAPA-1. J Biol Chem 266:14597-14602.

Lowry OH, Roscbrough NJ, Farr AL, Randall RJ (1951) Protcin measurement with the Folin phenol reagent. J Biol Chem 193:265275.

Marken JS, Schieven GL, Hellstrom I, Hellstrom KE, Aruffo A (1992) Cloning and expression of the tumor-associated antigen L6. Proc Natl Acad Sci USA 89:3503-3507.

Martin-Alonso JM, Hernando N, Ghosh S, Coca-Prados M (1992) Molecular cloning of the bovine CD9 antigen from ocular ciliary epithelial cells. J Biochem 112:63-67.

Masselis-Smith A, Jensen GS, Seehater JG, Slupsky JR, Shaw ARE (1990) Anti-CD9 monoclonal antibodies induce homotypic adhesion of pre-B cell lines by a novel mechanism. J Immunol 144:1607-1613.

Metzelaar MJ, Wijingaard PLJ, Peters LJ, Sixma JJ, Nieuwenhuis HK, Clevers HC (1991) CD63 antigen. A novel lysosomal membrane glycoprotein, cloncd by a screening procedure for intracellular antigens in eukaryotic cells. J Biol Chem 266:3239-3245.

Mitamura T, Iwamoto R, Umata T, Tomo Y, Urabe I, Tsuneoka M, Mekada E (1992) The 27-kD diphtheria toxin receptor-associated protein (DRAP27) from Vero cells is the monkey homologue of human CD9 antigen: expression of DRAP27 elevates the number of diphtheria toxin receptors on toxin-sensitive cells. J Cell Biol 118: 1389-1399.

Miyake M, Koyama M, Seno M, Ikeyama S (1991) Identification of the motility-related protein (MRP-1), recognized by monoclonal antibody M31-15, which inhibits cell motility. J Exp Med 174:13471354.

Nishikata H, Oliver C, Mergenhagen SE, Siraganian RP (1992) The rat mast cell antigen $A D 1$ (homologue to human $C D 63$ or melanoma antigen ME491) is expressed in other cells in culture. J Immunol 149: $862-870$.

Oren R, Takahashi S, Doss C, Levy R, Levy S (1990) TAPA-1, the target of an antiproliferative antibody, defines a new family of transmembrane proteins. Mol Cell Biol 10:4007-4015.
Reynolds SR, Shoemaker CB, Harn DA (1992) T and B cell epitope mapping of SM23, an integral membrane protein of Schistosoma mansoni. J Immunol 149:3995-4001.

Ross AH, Pleasure D, Sonnenfeld K, Atkinson B, Kreider B, Jackson DM, Taff I, Scarpini E, Lisak RP, Koprowski H (1986) Expression of melanoma-associated antigens by normal and neurofibroma schwann cells. Cancer Res 46:5887-5892.

Rubinstein E, Benoit P, Billard M, Plaisance S, Prenant M, Uzan G, Boucheix C (1993a) Organization of the human CD9 gene. Genomics 16:132-138.

Rubinstein E, Billard M, Plaisance S, Prenant M, Boucheix C (1993b) Molecular cloning of the mouse equivalent of CD9 antigen. Thromb Res 71:377-383.

Sanger F, Nicklen S, Coulson AR (1977) DNA sequencing with chainterminating inhibitors. Proc Natl Acad Sci USA 74:5463-5467.

Slupsky JR, Seehafer JG, Tang SC, Masselis-Smith A, Shaw ARE (1989) Evidence that monoclonal antibodies against $C D 9$ antigen induce specific association between CD9 and the platelet glycoprotein IIbIIIa complex. J Biol Chem 264:12289-12293.

Smith DB, Johnson KS (1988) Singlc-stcp purification of polypeptides expressed in Escherichia coli as fusions with glutathione S-transferase. Gene 67:31-40.

Snipes GJ, Suter U, Welcher AA, Shooter EM (1992) Characterization of a novel peripheral nervous system myelin protein (PMP-22/SR 13). J Cell Biol 117:225-238.

Snipes GJ, Suter U, Shooter EM (1993) The genetics of myelin. Curr Opin Neurobiol 3:694-702.

Stahl N, Harry J, Popko B (1990) Quantitative analysis of myelin protein gene expression during development in the rat sciatic nerve. Mol Brain Res 8:209-212.

Steinman L (1993) Connections between the immune and the nervous system. Proc Natl Acad Sci USA 90:7912-7914.

Suter U, Welcher AA, Snipes GJ (1993) Progress in the molecular understanding of hereditary peripheral ncuropathics reveals new insights into the biology of the peripheral nervous system. Trends Neurosci $16: 50-56$.

Suzue T, Kaprielian Z, Patterson PH (1990) A monoclonal antibody that defines rostrocaudal gradients in the mammalian nervous system. Neuron 5:421-431.

Szala S, Kasai Y, Steplewski Z, Rodeck U, Koprowski H, Linnebach AJ (1990) Molecular cloning of cDNA for the human tumor-associated antigen $\mathrm{CO}-029$ and identification of related transmembrane antigens. Proc Natl Acad Sci USA 87:6833-6837.

Tole S, Patterson PH (1993) Distribution of CD9 in the developing and mature rat nervous system. Dev Dynamics 197:94-106.

Tomlinson MG, Williams AF, Wright MD (1993) Epitope mapping of anti-rat CD53 monoclonal antibodies. Implications for the membrane orientation of the transmembrane 4 superfamily. Eur J Immunol 23:136-140.

Von dem Borne AEGK, Modderman PW, Admiraal LG, Nieuwenhuis HK (1989) Platelet antibodies, the overall results. In: Leukocyte typing, white cell differentiation antigens, 4:951-966.

Welcher AA, Suter U, Leon MD, Snipes GJ, Shooter EM (1991) A myelin protein is encoded by the homologue of a growth arrest-specific gene. Proc Natl Acad Sci USA 88:7195-7199.

Wiggins RC, Benjamins JA, Morell P (1975) Appearance of myelin proteins in rat sciatic nerve during development. Brain Res 89:99106.

Wright MD, Henkle KJ, Mitchell GF (1990) An immunogenic Mr 23,000 integral membrane protein of Schistosoma mansoni worms that closely resembles a human tumor-associated antigen. J Immunol 144:3195-3200.

Wright MD, Rochelle JM, Tomlinson MG, Seldin MF, Williams AF (1993) Gene structure, chromosomal localization, and protein sequence of mouse CD53 ( $C d 53$ ): evidence that the transmembrane 4 superfamily arose by gene duplication. Int Immunol 5:209-216. 